\title{
Anatomical Observation and Proteomics Analysis of Root Tips of Wild and Cultivated Soybeans
}

\author{
Chao Yu, ${ }^{1,2}$ XiFeng Zhang ${ }^{2}$, Feng $\mathrm{Li}^{2}$, Qiying $\mathrm{Cai}^{2}$, Xin $\mathrm{Yan}^{2}$, Shaobo $\mathrm{Li}^{2}$ and Youlin $\mathrm{Zhu}^{1,2^{*}}$ \\ ${ }^{1}$ State Key Laboratory of Food Science and Technology, Nanchang University, Nanchang 330031, Jiangxi, China \\ ${ }^{2}$ Key Laboratory of Molecular Biology and Gene Engineering in Jiangxi Province, College of Life Science, Nanchang \\ University, Nanchang 330031, China \\ *For correspondence: ylzhu1999@aliyun.com
}

\begin{abstract}
Wild and cultivated soybeans from different areas of China were used as materials for paraffin cross-sections of the juncture between the root elongation and maturation zones of wild and cultivated soybeans during the seedling stage. It was found that the casparian band of the endodermis and duct of metaxylem in the anatomical structure of the cultivated soybean developed faster than those of the wild soybean. Rapid development of these structures sped up transmission and enhanced support capacity. Meanwhile, two-dimensional electrophoresis was adopted to analyze the differences between the wild and cultivated soybean populations in terms of protein expression during the seedling stage. Our results showed that expression levels of 28 proteins from among the wild and cultivated soybean populations were significantly different from one another. In the cultivated population, the protein expression levels were up-regulated in four protein spots and down-regulated in 24 protein spots. Down-regulated proteins were associated with secondary metabolites and metabolism of antibiotics. Decrease in the expression these proteins may speed up nodule formation. These results showed that early growth and development of the cultivated soybean roots occurred at a significantly faster rate than those of the wild soybean. The increased rates of these processes accelerate root shape formation and improve root function. In conclusion, this study systematically explored the anatomical structure and differentially expressed proteins of roots between wild and cultivated soybean, and differentially expressed proteins identified here will be the valuable resource for studying soybean root differences resulting from domestication. (C) 2017 Friends Science Publishers
\end{abstract}

Keywords: Soybeans; Domestication; Root; Anatomical structure; Protein expression difference

\section{Introduction}

Cultivated soybean [Glycine max (L.) Merr.] is domesticated from the wild soybean, and this process has caused significant changes to soybean roots. As compared to wild soybeans, modern cultivated soybeans have conspicuous primary roots and decreased lateral roots, and the former has increased root diameter, number of ducts at the secondary xylem, duct diameter, and number of secondary vascular rays (Wang et al., 2000; Zhu et al., 2003). Differences in root between wild and cultivated soybeans appear at the seedling stage. The extent and depth of root spreading in cultivar are remarkably higher than wild soybean, leading to the improvement on abilities of support and absorption in root (Manavalan et al., 2015; Prince et al., 2015). Therefore, it is extremely important to identify the differences in the early growth and development of roots between wild and cultivated soybean roots and to explore the mechanism of soybean root evolution in domestication.

Proteomics analysis is an effective method that facilitates the exploration of physiological and biochemical processes (Mathesius et al., 2011; Chen et al., 2016; Wang et al., 2016). Two-dimensional gel electrophoresis (2-DE) has been used to analyze the differences between wild and cultivated soybean seeds in terms of protein composition ( $\mathrm{Li}$ et al., 2007; Xu et al., 2007; Natarajan et al., 2012). However, as far as we know, the difference between the proteome of wild soybean roots and that of cultivated soybean roots has not yet been reported.

In this paper, the anatomical structures of the root tips of landraces of wild soybeans were compared to those of cultivated soybeans by examining paraffin sections of the root tips. Meanwhile, 2-DE was used to analyze the proteome of the root tips from the wild and cultivated soybean roots for exploring their differences in regards to their early growth and development. Our findings are not only useful for studying the mechanism of root difference formation between wild and cultivated soybeans, but also helpful for revealing the molecular mechanism of domestication.

To cite this paper: Yu, C., X. Zhang, F. Li, Q. Cai, X. Yan, S. Li and Y. Zhu, 2017. Anatomical observation and proteomics analysis of root tips of wild and cultivated soybeans. Int. J. Agric. Biol., 19: 849-856 


\section{Materials and Methods}

\section{Experimental Materials}

Soybean [Glycine max (L.) Merr.] seeds were placed on wet absorbent gauze at $27^{\circ} \mathrm{C}$ in darkness for $20 \mathrm{~h}$ to allow germination. The seeds whose radicles slightly penetrated the seed coats were selected and planted in wet autoclaved vermiculites and then grown at $27^{\circ} \mathrm{C}$ for $27 \mathrm{~h}$. The seedlings that were higher than the vermiculite and had similar heights were selected, and their main roots were cut off for subsequent testing.

For the anatomical structure observations, six wild soybeans and six cultivated soybeans were collected from different areas of China (Table 1). Under a stereoscope, a $0.5 \mathrm{~cm}$ section was cut from the bottom of the maturation zone (root hair zone) to the elongation zone. To make the paraffin section, it was fixed in FAA (alcohol $55 \% 89 \mathrm{~mL}+$ glacial acetic acid $6 \mathrm{~mL}$ + formalin $5 \mathrm{~mL}$ ) for $24 \mathrm{~h}$.

For the proteome and quantitative real-time reverse transcription polymerase chain reaction (qRT-PCR) analyses, a $1.5 \mathrm{~cm}$ section was cut from the top of the main roots. And we took 40 wild soybeans and 40 cultivars as two samples separately (Table 2) for balanced mixing (D'Ambrosio et al., 2012).

\section{Production of Paraffin Section}

The fixed root segments were stained with Mayer's hematoxylin for 3 days. The loose color on the segments was removed through immersion cleaning with distilled water (six times, 10min each time), and then, the fixed segments were cleaned with running tap water for $12 \mathrm{~h}$ for bluing. Then, different concentrations of alcohol $(15,30,45$, $60,70,80,90$ and $95 \%$ for $15 \mathrm{~min}$; three times with anhydrous alcohol, $20 \mathrm{~min}$ each time) were used to dehydrate the segments. Chloroform and ethyl alcohol transparent agents were then applied $(1: 2,1: 1,2: 1$, each for $6 \mathrm{~h}$; three times with absolute chloroform, $3 \mathrm{~h}$ each time). Chloroform paraffin $(25,50,75,100 \%$ wax, each for $3 \mathrm{~h})$ was used to embed the segments. After embedding, the sections were sliced with Leica RM2125RTSat at thickness of $10 \mu \mathrm{m}$. The slices were unfolded, affixed, and then dried for $2 \mathrm{~h}$ at $45^{\circ} \mathrm{C}$. They were subsequently dewaxed with xylene at $35^{\circ} \mathrm{C}$ and sealed with neutral balsam. The images were obtained under an OLYMPUS CX-41 microscope.

\section{Proteome Analysis}

Protein extract and 2-DE were carried out according to the previous study (Xu et al., 2007). Bio-Protein Assay Kit (5000202, 5000203) was used to determine the protein concentrations in the samples. Nonlinear strips $(17 \mathrm{~cm})$ with $\mathrm{pH}$ of 3-10 (Bole Company) were used, and the protein loading amount was $290 \mu \mathrm{g}$. Silver staining was performed according to the method of Zhu et al. (1999), and a Tif
Table 1: Soybean materials for anatomical analysis

\begin{tabular}{lll}
\hline Source area & Wild soybeans & Cultivated soybeans \\
\hline Heilongjiang & ZYD00693 & Lin Dian Shuai Yi Ling \\
Shandong & ZYD03234 & Mo Shi Da Dou \\
Jiangsu & ZYD04111 & Liu He Hong Mao Qing Zao \\
Sichuan & ZYD04318 & Wan Xian Bai Dong Dou \\
Yunnan & ZYD05173 & ShuangBaiTuo Dian Hei Pi \\
Guangxi & ZYD05218 & Yu Lin Da Huang Dou \\
\hline
\end{tabular}

Table 2: Soybean material list

\begin{tabular}{|c|c|c|c|}
\hline \multicolumn{2}{|c|}{ Wild soybeans } & \multicolumn{2}{|c|}{ Cultivated soybeans } \\
\hline Name & Source area & Name & Source area \\
\hline ZYD00693 & Heilongjiang & Jian Yang Qiu Da Dou & Fujian \\
\hline ZYD04429 & Zhejiang & Yu Lin Da Huang Dou & Guangxi \\
\hline ZYD04609 & Jiangxi & Wan Xian Bai Dong Dou & Sichuan \\
\hline ZYD01030 & Jilin & Zhen Ba Xiao Bai Huang Dou & Shaanxi \\
\hline ZYD02213 & Liaoning & MiLuo Dou Ban Jin & Hunan \\
\hline ZYD02726 & Beijing & Yu Hang Liu Yue Dou & Zhejiang \\
\hline ZYD02891 & Shanxi & ShuangBaiTuo Dian Hei Pi & Yunnan \\
\hline ZYD03234 & Shandong & Xu Chang BaiHua Cao & Henan \\
\hline ZYD03296 & Gansu & Tong Shan Liu Yue Huang & Hubei \\
\hline ZYD03387 & Henan & Chi Feng Xiao Qing Dou & Neimenggu \\
\hline ZYD03718 & Shaanxi & RenHua Ba Yue Huang & Guangdong \\
\hline ZYD04111 & Jiangsu & Mo Shi Da Dou & Shandong \\
\hline ZYD04200 & Anhui & Su Xian Xiao Hei Dou & Anhui \\
\hline ZYD04318 & Sichuan & Lin Dian Shuai Yi Ling & Heilongjiang \\
\hline ZYD04390 & Hubei & Xiao Bai Mei & Jilin \\
\hline ZYD04666 & Hunan & Liu He Hong Mao Qing Zao & Jiangsu \\
\hline ZYD04853 & Fujian & HengFeng Ma Yi Dou & Jiangxi \\
\hline ZYD05173 & Yunnan & Tong Xian Huang Dou & Beijing \\
\hline ZYD05190 & Guangdong & Yang Yan Jing Dou & Gansu \\
\hline ZYD05218 & Guangxi & Niu Pi Huang & Hebei \\
\hline ZYD05715 & Neimenggu & Xu Yong Xiao BaiShui Dou & Sichuan \\
\hline ZYD00609 & Heilongjiang & BaoLuo Huang & Zhejiang \\
\hline ZYD03261 & Shandong & Da Li Huang & Heilongjiang \\
\hline ZYD03489 & Henan & XuJia Ying Huang Dou & Ningxia \\
\hline ZYD04008 & Shaanxi & Chang Ji Huang Dou No.1 & Xinjiang \\
\hline ZYD04174 & Jiangsu & Yang Yan Jing Dou & Shanxi \\
\hline ZYD04260 & Anhui & Da Dou & Shaanxi \\
\hline ZYD04410 & Hubei & Qing Pu Hong Dou & Shanghai \\
\hline ZYD04541 & Zhejiang & Cha Huang Dou & Hubei \\
\hline ZYD04560 & Zhejiang & Sa Dou & Yunnan \\
\hline ZYD04591 & Xizang & Da Huang Dou No.1 & Guangdong \\
\hline ZYD04597 & Jiangxi & Da Ke Huang & Guangxi \\
\hline ZYD04679 & Hunan & Huang Dou & Shanxi \\
\hline ZYD04741 & Guizhou & Huang Chi Da Huang Dou & Anhui \\
\hline ZYD04762 & Guizhou & Zhen Jiang Huang Dou & Jiangsu \\
\hline ZYD04876 & Fujian & Wei NingZongZi Dou & Guizhou \\
\hline ZYD05176 & Guangdong & Gui Xi Ma Yi & Jiangxi \\
\hline ZYD05242 & Guangxi & Quan Zhou Shi Tang Wu Yue & Guangxi \\
\hline ZYD05473 & Jilin & She Xian JieChuanHei Dou & Anhui \\
\hline ZYD06284 & Hebei & Yi Xian Hei Dou & Hebei \\
\hline
\end{tabular}

format image was obtained by scanning.

Images of 2-DE were obtained and then analyzed with ImageMaster2D Platinum 6.0 software. The relative gray value (vol\%) was selected as the index. According to the ratio value criteria $(>2$ or $<0.5)$, differentially expressed protein spots were found among the wild and cultivated populations. The relative gray values were analyzed by t-test to determine the candidate protein spots, and the differentially expressed protein spots were finally determined $(P<0.05$ was considered significant). 
Mass spectrometry was performed according to the method of Wang et al. (2013). A 4800 MALDI TOF/TOF series time-of-flight mass spectrometer was used to perform peptide mass fingerprinting (PMF) identification. The NCBI database was then searched. Protein functional analysis and clustering were performed in the David, KEGG and Phytozome website.

\section{qRT-PCR}

qRT-PCR was performed according to the earlier study Wang et al. (2014), and details of the primers used in this assay were listed in Table 3.

\section{Results}

\section{Structures of the Wild and Cultivated Soybean Root Tips}

The structures of the juncture between the root elongation and maturation zones of the root tips of the wild and cultivated soybeans were observed. Both soybean accessions had clearly identifiable as epidermis, cortex, and protoxylem as well as contained a tetrarch radial stele. Root structures of the cultivated soybeans developed more rapidly than those of the wild soybeans. Likewise, the endodermis of the cultivated soybeans developed earlier than that of the wild soybeans. In cultivars, some cells had increased cell wall thickness and casparian bands formed. While no such structure was observed in wild soybeans. Furthermore, the metaxylems of the cultivated soybeans developed earlier than those of the wild soybeans. In the cultivated soybeans, cells at the corresponding locations of the metaxylems were regular polygonal and arranged in neat rows, and their cell walls were considerably thicker than those in the wild soybeans. Furthermore, the corresponding location in the wild soybean still had parenchyma cells with weak differentiation (Fig. 1a, b). In addition, the cultivated soybeans had thicker roots than the wild soybeans. Diameters of root and the vascular column in cultivated soybean roots were $0.72 \pm 0.05$ and $0.26 \pm 0.04 \mathrm{~mm}$, respectively, whereas those of the wild soybeans were $0.53 \pm 0.05$ and $0.19 \pm 0.02 \mathrm{~mm}$, respectively. There were significant differences between the soybean groups in terms of root and vascular column diameters (Fig. 1c).

\section{Protein Expression in Root Tips of Wild and Cultivated Soybeans}

Approximately $896 \pm 52$ and $887 \pm 43$ protein spots were detected in the two-dimensional electrophoretograms of both the populations. A total of 28 differentially expressed protein spots were found between the wild and the cultivated populations. As compared to the wild population, the cultivated population displayed significant up-regulation and down-regulation in 4 and 24 of the protein spots, respectively (Fig. 2). A total of 28 differentially expressed
Table 3: Primers for fluorescent quantitative PCR

\begin{tabular}{|c|c|c|}
\hline Protein NO & Gene & Primer sequence (5'to3') \\
\hline \multirow[t]{2}{*}{1} & Glyma16g08460 & ACTCAAAGGGTTTGATTGTTGG \\
\hline & & CTCACTCCATTCGTAAGCCTC \\
\hline \multirow[t]{2}{*}{3} & Glyma08g23860 & TAGTAAGAGCACTCGACAGTGG \\
\hline & & TCTGACAACACCTCAGGAGC \\
\hline \multirow[t]{2}{*}{9} & Glyma03g40680 & CAATTAGGAGGGCACATGCTG \\
\hline & & TCCAAGTTCCCTGCAAAGTG \\
\hline \multirow[t]{2}{*}{10} & Glyma13g20790 & GGAACTGAAATTGACCCTAGAACC \\
\hline & & CTCTCACAACCTGATGTTCAAGTC \\
\hline \multirow[t]{2}{*}{12} & Glyma05g27260 & AAATCTGGGCATGAACTTCTC \\
\hline & & AAGGAGTTCTCAGCAATAGGT \\
\hline \multirow[t]{2}{*}{14} & Glyma11g15680 & TCACACTATTGGAGCTGCAC \\
\hline & & ATATTTATCAACGAGAGGGCGG \\
\hline \multirow[t]{2}{*}{15} & Glyma10g15910 & CCTCAGTCTCTCACTCGCAG \\
\hline & & TAGCCTCCGAACATCTTGCC \\
\hline \multirow[t]{2}{*}{17} & Glyma03g27580 & TGTTGAAGAAGGTGATGCATCTG \\
\hline & & ATGTATGTGTCAGAAGTCGGG \\
\hline \multirow[t]{2}{*}{20} & Glyma07g06570 & TGAAACACCAGCAGAAGGAC \\
\hline & & AAATCAAGGTCTCCCAACCC \\
\hline \multirow[t]{2}{*}{21} & Glyma14g11711 & GAAGGATCTGGAAGCTGTCG \\
\hline & & TCCAACATCCTTGAGCATCTG \\
\hline \multirow[t]{2}{*}{22} & Glyma13g32300 & CTACAGAGACAGGGAGACAAGAC \\
\hline & & AATGTTTCAGGTACCTGCCAC \\
\hline \multirow[t]{2}{*}{ Reference gene } & GlycineACTIN & GGCAAGTCCAATCCACAAG \\
\hline & & AGGAAGGGTGTGCTTCTCC \\
\hline
\end{tabular}

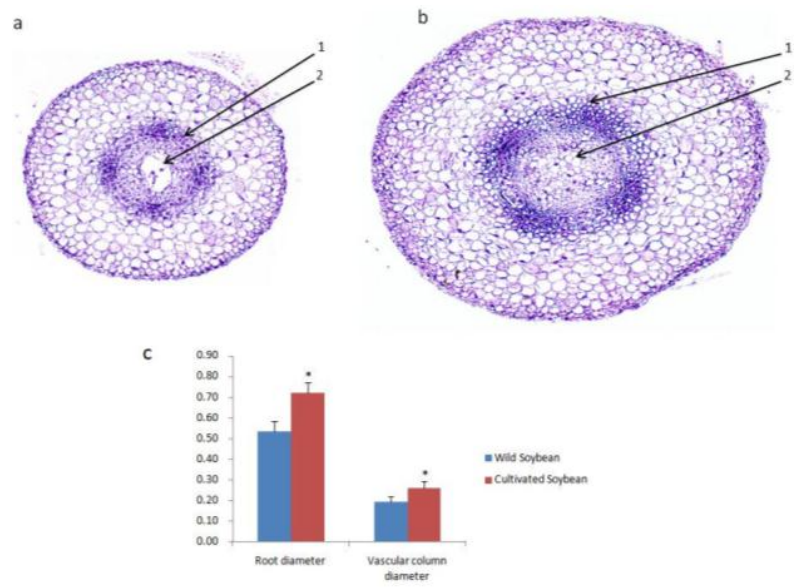

Fig. 1: Comparison between the anatomical structures of the wild and cultivated soybean roots (juncture of elongation and root hair zones)

a. Cross-section of wild soybean roots; b. Cross-section of cultivated soybean roots; c. Comparison between the root and vascular column diameters of the wild and cultivated soybeans, * means the significant difference ( $t$-test, $\mathrm{p}<0.05) ; 1$. Endodermis, the casparian band of the endodermis is forming in cultivated soybean; 2. metaxylem, duct of metaxylem is forming in cultivated soybean

protein spots were identified by PMF performed on ABI 4800 MALDI TOF/TOF. Later on information related to 25 of the differentially expressed protein spots was obtained from the NCBInr database (Table 4).

\section{Functional Analysis of Differentially Expressed Protein}

David, KEGG, and Phytozome analyses were used to determine the functions of these proteins (Table 5). We 


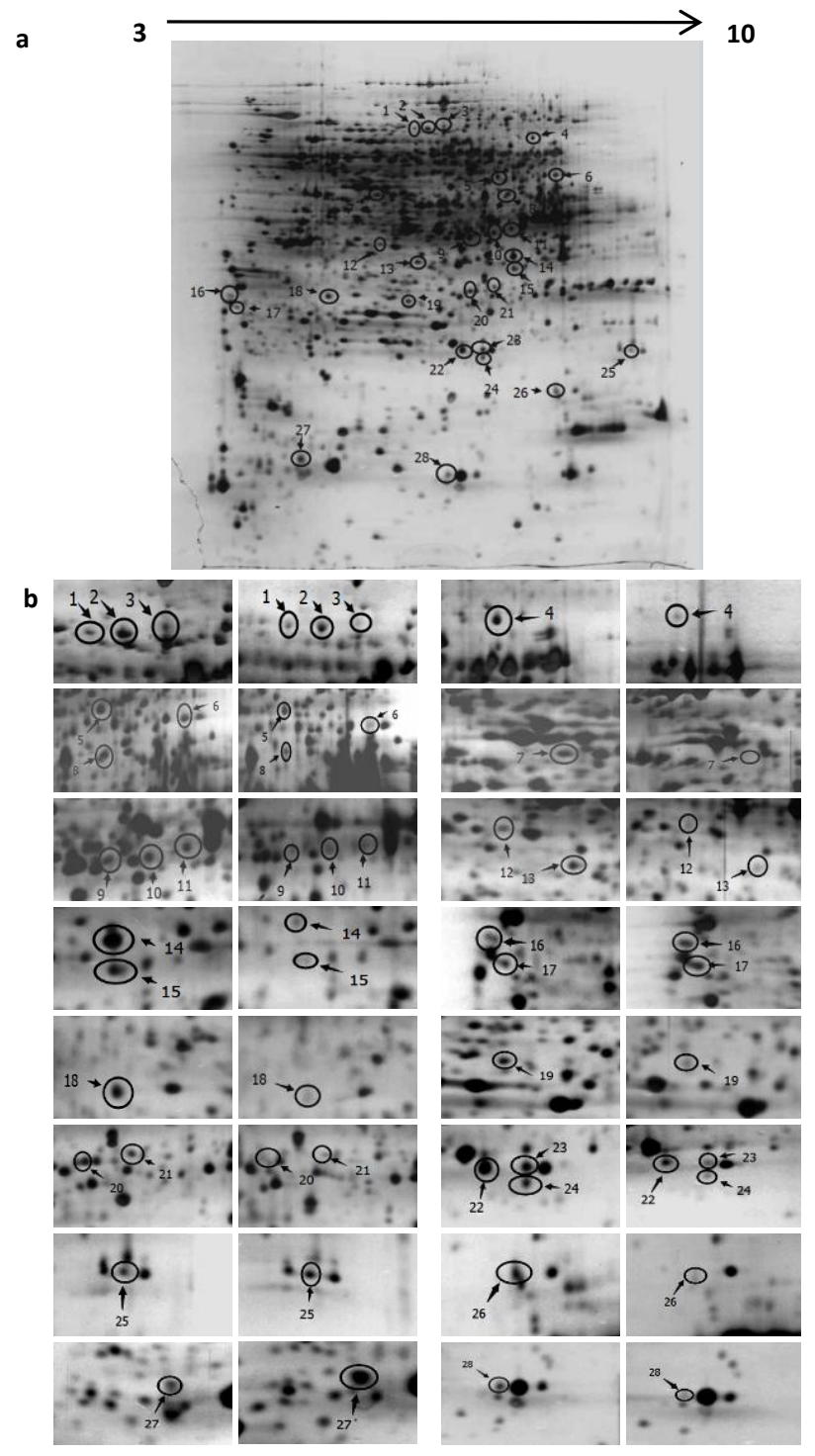

Fig. 2: Differentially expressed protein spots in root tips of wild and cultivated soybean populations

a. Scheme diagram of differentially expressed protein spots in the wild and cultivated soybean root tips; b. Differential protein spots between two soybean populations. Left side is the wild population; right side is the cultivated population

found that down-regulated proteins were enriched on metabolic pathways, carbon metabolism, biosynthesis of secondary metabolites, biosynthesis of antibiotics, pyruvate metabolism, glycolysis/gluconeogenesis (Fig. 3). These proteins were primarily concentrated in two aspects: that involving carbon, sugar and energy metabolism and that involving secondary metabolites and antibiotics metabolism.

\section{Transcriptional Analysis of Differentially Expressed Protein-Encoding Genes}

Eleven differentially expressed proteins were randomly

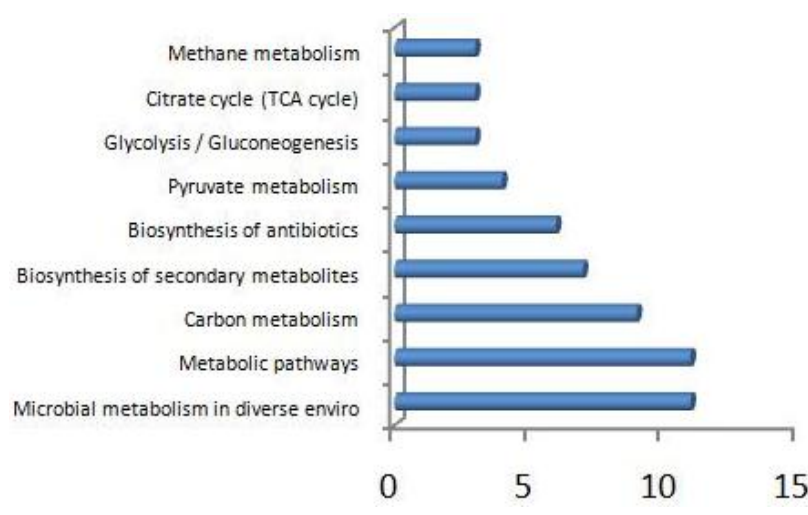

Fig. 3: Functional analyses of differentially expressed proteins in the root tips of wild and cultivated populations

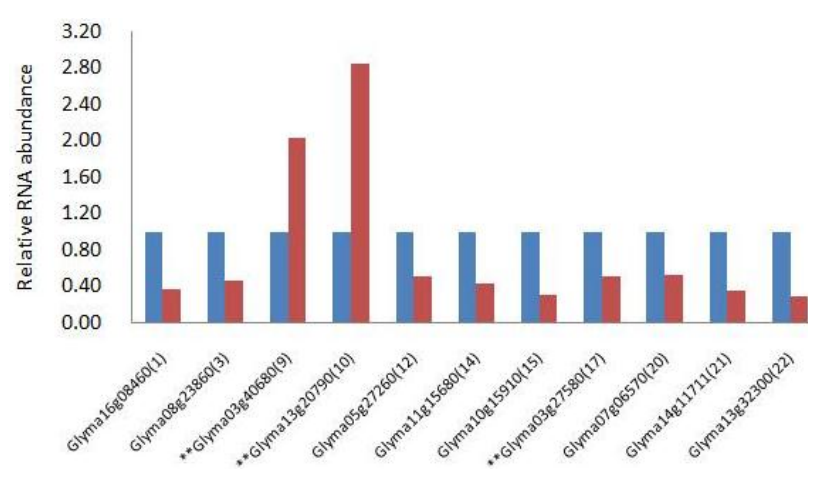

Fig. 4: Transcription levels of the encoding genes of differentially expressed proteins in the root tips of wild and cultivated soybean populations

** Glyma03g40680 (9): ** In the wild and cultivated soybeans, the genes whose changes of transcription levels are not consistent with the expression level of protein, Glyma03g40680 gene number, (9) number of differentially expressed protein spots

taken to further check transcriptional levels of these differentially expressed protein-coding genes in the wild and cultivated soybeans. QRT-PCR analysis was performed on the root tip samples from the wild and cultivated soybeans. Our results showed that for eight of the differentially expressed proteins, the possible encoding genes exhibited transcription level changes that were consistent with the protein expression levels; however, those of the other three differentially expressed proteins were not consistent (Fig. 4).

\section{Discussion}

Early root growth and development occurred more rapidly in the cultivated soybean roots than in the wild soybean roots. After observing the cross-section of the juncture between the elongation and maturation zones of the wild and cultivated soybeans, it was determined that the casparian band and metaxylem duct in the endodermis developed much more quickly in the cultivated soybeans than in the wild soybeans. This finding is consistent with the 
Table 4: Spectrum identification of the differentially expressed proteins in the wild and cultivated root tips

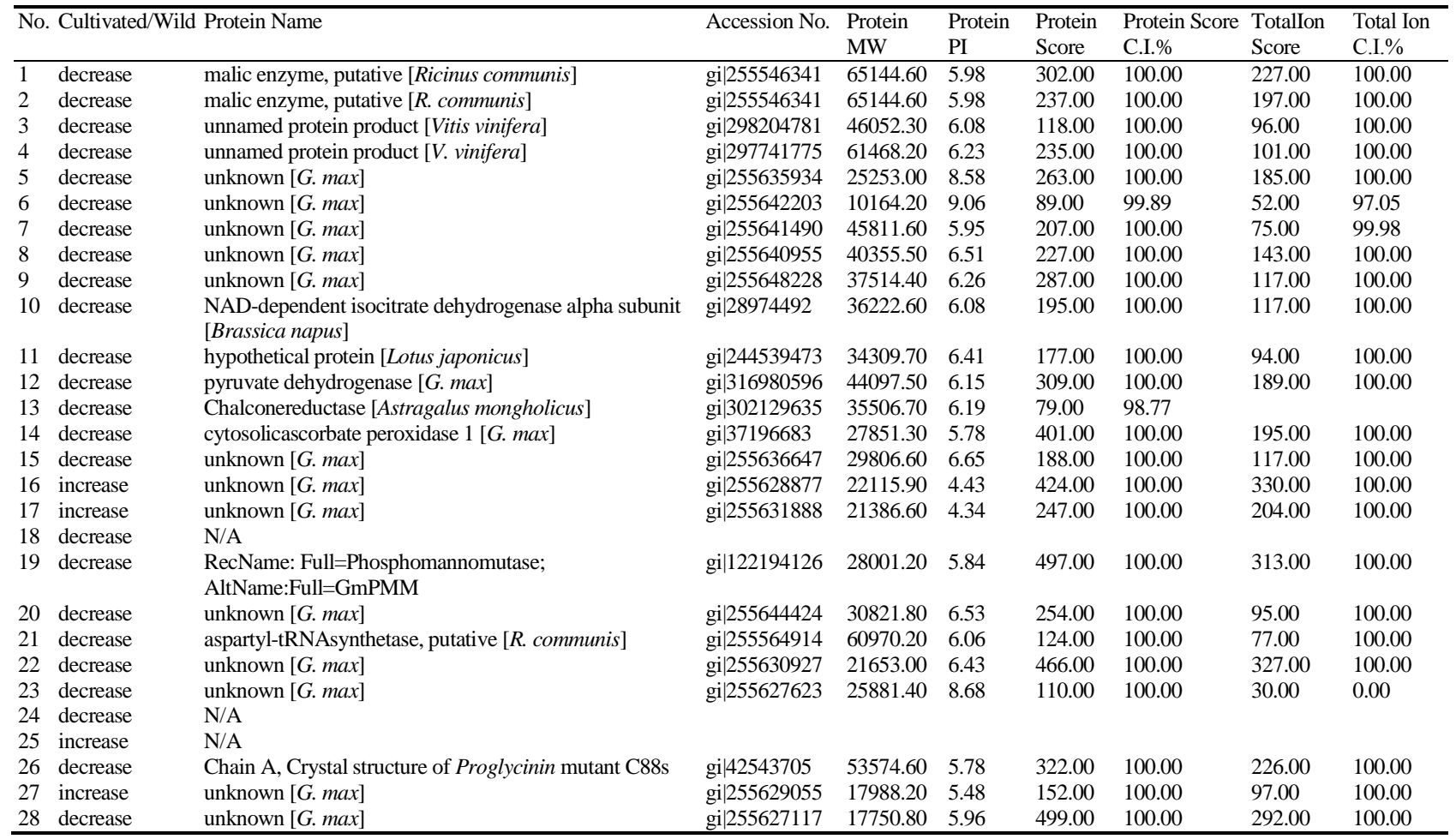

morphological differences in roots between cultivated and wild soybeans at the seedling stage (Manavalan et al., 2015; Prince et al., 2015). Rapid early growth and development of cultivated soybean roots are conducive to root shape formation and its functioning. The formation of the casparian band in the endodermis is associated with the formation of the vascular column, which facilitates the transport of substances in the vascular column. Moreover, the fast development of the metaxylem duct undoubtedly contributes to the transportation of substances, and the thickening of the cell walls of these structures improves the support function of the roots.

Soybean roots contain bacteria in the nodule for nitrogen fixation, which is apart from conduction or support (Munoz et al., 2016). In our results, as compared to the wild soybeans, the cultivated soybeans essentially exhibited a decreasing trend in the protein expression levels in their root tips. Interestingly, the decreased protein expression levels were primarily related to secondary metabolites and antibiotics metabolism, which contribute to nodule formation caused by the invasion of nodule bacteria. In addition, it has known that plant stress response has the association with secondary metabolites or antibiotics metabolism. And there is a balance between stress resistance and growth in plant (Deng et al., 2017). Therefore, downregulated genes related to secondary metabolites and antibiotics metabolism may lead to the faster root growth in cultivated soybean.

In regards to the differentially expressed proteins from the root tips of wild and cultivated soybeans, it is likely that useful genes can be identified that can improve the root morphology and function of the modern cultivated soybean. In the domestication process, the artificial selection pressure is oriented. Accordingly, important economic and agronomic traits of crops have been improved as a result of accumulating beneficial genes (Yamasaki et al., 2007). The published genomic information of cultivated soybeans differs somewhat from that of wild soybeans (Kim et al., 2010; Schmutz et al., 2010). In recent years, some researchers have constructed quantitative trait loci (QTLs) related to population exploration and root morphology by using cultivated and wild soybeans as parents (Liang et al., 2014; Manavalan et al., 2015; Prince et al., 2015). However, in this approach, the beneficial target gene is difficult to directly map. Proteomics analysis used here can complement the QTL study, which accelerates the process of functional genes identification through combining two approaches together.

\section{Conclusion}

Here we characterized 28 differentially expressed proteins between wild and cultivated soybean populations. Potential functions of these proteins and their correlation with root morphological difference between these soybeans at the seedling stage were studies. Our results are beneficial for understanding the mechanism of root difference directed by domestication and then genes found here are potential valuable for soybean breeding in future. 
Yu et al. / Int. J. Agric. Biol., Vol. 19, No. 4, 2017

Table 5: Function analysis of differentially expressed proteins of the root tips of the wild and cultivated populations

\begin{tabular}{|c|c|c|c|c|c|c|c|}
\hline $\begin{array}{l}\text { Cultivated: } \\
\text { Wild }\end{array}$ & Accession No. & Protein Name & DAVID & $\mathrm{KO}$ & KEGG & Gene & Phytozome \\
\hline decrease & gi|255546341 & $\begin{array}{l}\text { Malic enzyme, putative } \\
\text { [Ricinus communis] }\end{array}$ & $\begin{array}{l}\text { NADP-dependent } \\
\text { malic enzyme } \\
\text { (LOC8268296) }\end{array}$ & K00029 & $\begin{array}{l}\text { Microbial metabolism in diverse } \\
\text { environments, Metabolic pathways, } \\
\text { Carbon metabolism, Pyruvate } \\
\text { metabolism, Carbon fixation in } \\
\text { photosynthetic organisms }\end{array}$ & Glyma16g08460 & $\begin{array}{l}(\mathrm{M}=5) \\
\text { PTHR23406:SF26 - } \\
\text { NADP-dependent } \\
\text { Malic Enzyme 1 }\end{array}$ \\
\hline decrease & gi|255546341 & $\begin{array}{l}\text { malic enzyme, putative } \\
{[R . \text { communis }]}\end{array}$ & $\begin{array}{l}\text { NADP-dependent } \\
\text { malic enzyme } \\
\text { (LOC8268296) }\end{array}$ & K00029 & $\begin{array}{l}\text { Microbial metabolism in diverse } \\
\text { environments, Metabolic pathways, } \\
\text { Carbon metabolism, Pyruvate } \\
\text { metabolism, Carbon fixation in } \\
\text { photosynthetic organisms }\end{array}$ & Glyma16g08460 & $\begin{array}{l}(\mathrm{M}=5) \\
\text { PTHR23406:SF26 - } \\
\text { NADP-dependent } \\
\text { Malic Enzyme 1 }\end{array}$ \\
\hline decrease & gi|298204781 & $\begin{array}{l}\text { unnamed protein product } \\
\text { [Vitis vinifera }]\end{array}$ & $\begin{array}{l}\text { D-3- } \\
\text { phosphoglycerate } \\
\text { dehydrogenase 3, } \\
\text { chloroplastic-like } \\
\text { (LOC100241666) }\end{array}$ & K00058 & $\begin{array}{l}\text { Microbial metabolism in diverse } \\
\text { environments, Metabolic pathways, } \\
\text { Carbon metabolism, Biosynthesis of } \\
\text { antibiotics, Methane metabolism, } \\
\text { Biosynthesis of amino acids, Glycine, } \\
\text { serine and threonine metabolism }\end{array}$ & Glyma08g23860 & $\begin{array}{l}(\mathrm{M}=5) \text { 1.1.1.95 - } \\
\text { Phosphoglycerate } \\
\text { dehydrogenase, } \\
\text { Phosphoglyceric acid } \\
\text { dehydrogenase }\end{array}$ \\
\hline decrease & gi|297741775 & $\begin{array}{l}\text { unnamed protein product } \\
{[\text { V. vinifera }]}\end{array}$ & $\begin{array}{l}\text { pyrophosphate-- } \\
\text { fructose 6- } \\
\text { phosphate } 1- \\
\text { phosphotransferase } \\
\text { subunit beta } \\
\text { (LOC100256839) }\end{array}$ & K00895 & $\begin{array}{l}\text { Microbial metabolism in diverse } \\
\text { environments, Metabolic pathways, } \\
\text { Biosynthesis of secondary metabolites, } \\
\text { Biosynthesis of antibiotics, Glycolysis } \\
\text {, Gluconeogenesis, Fructose and } \\
\text { mannose metabolism, Pentose } \\
\text { phosphate pathway }\end{array}$ & Glyma15g11890 & $\begin{array}{l}\text { pyrophosphate-- } \\
\text { fructose-6-phosphate } \\
\text { 1-phosphotransferase } \\
\text { [EC:2.7.1.90] }\end{array}$ \\
\hline decrease & gi|255635934 & unknown [Glycine max] & $\begin{array}{l}\text { probable N- } \\
\text { succinyldiaminopi } \\
\text { melate } \\
\text { aminotransferase } \\
\text { DapC } \\
\text { (LOC100818968) }\end{array}$ & - & & Glyma06g11640 & $\begin{array}{l}(\mathrm{M}=3) \\
\text { PTHR11751,PTHR1 } \\
\text { 1751:SF317 - } \\
\text { SUBGROUP I } \\
\text { Aminotransferase } \\
\text { related }\end{array}$ \\
\hline decrease & gi|255642203 & unknown $[G . \max ]$ & $\begin{array}{l}\text { umaratehydratase } \\
1, \text { mitochondrial } \\
\text { (LOC100813552) }\end{array}$ & K01679 & $\begin{array}{l}\text { Microbial metabolism in diverse } \\
\text { environments, Metabolic pathways, } \\
\text { Carbon metabolism, Biosynthesis of } \\
\text { secondary metabolites, Biosynthesis of } \\
\text { antibiotics, Citrate cycle (TCA cycle), } \\
\text { Pyruvate metabolism, Renal cell } \\
\text { carcinoma, Pathways in cancer, } \\
\text { Carbon fixation pathways in } \\
\text { prokaryotes }\end{array}$ & Glyma02g01930 & $\begin{array}{l}(\mathrm{M}=4) 4.2 .1 .2- \\
\text { Fumaratehydratase, } \\
\text { Fumarase }\end{array}$ \\
\hline decrease & gi|255641490 & unknown $[G . \max ]$ & $\begin{array}{l}\text { fumarylacetoacetas } \\
\text { e-like } \\
\text { (LOC100817986) }\end{array}$ & K01555 & $\begin{array}{l}\text { Microbial metabolism in diverse } \\
\text { environments, Metabolic pathways, } \\
\text { Tyrosine metabolism, Styrene } \\
\text { degradation }\end{array}$ & Glyma09g01270 & $\begin{array}{l}(\mathrm{M}=2) \text { 3.7.1.2 - } \\
\text { Fumarylacetoacetase, } \\
\text { Fumarylacetoacetate }\end{array}$ \\
\hline decrease & gi|255640955 & unknown [G. $\max ]$ & $\begin{array}{l}\text { alcohol } \\
\text { dehydrogenase } \\
\text { class-3-like } \\
\text { (LOC100816775) }\end{array}$ & K00121 & $\begin{array}{l}\text { Microbial metabolism in diverse } \\
\text { environments, Metabolic pathways, } \\
\text { Carbon metabolism, Biosynthesis of } \\
\text { secondary metabolites, Biosynthesis of } \\
\text { antibiotics, Glycolysis, } \\
\text { Gluconeogenesis, Methane } \\
\text { metabolism, Tyrosine metabolism, } \\
\text { Chemical carcinogenesis, Metabolism } \\
\text { of xenobiotics by cytochrome P450, } \\
\text { Fatty acid degradation, Degradation of } \\
\text { aromatic compounds, Naphthalene } \\
\text { degradation, Chloroalkane and } \\
\text { chloroalkene degradation, Drug } \\
\text { metabolism - cytochrome P450, } \\
\text { Retinol metabolism }\end{array}$ & Glyma19g35340 & $\begin{array}{l}(\mathrm{M}=3) \\
\text { 1.1.1.1,1.1.1.284,,1.2. } \\
\text { 1.1 - Alcohol } \\
\text { dehydrogenase , } \\
\text { Aldehyde reductase , } \\
\text { S- } \\
\text { (hydroxymethyl)glutat } \\
\text { hione dehydrogenase, } \\
\text { NAD-linked } \\
\text { formaldehyde } \\
\text { dehydrogenase（基因 } \\
\text { ) }\end{array}$ \\
\hline decrease & gi|255648228 & unknown $[G . \max ]$ & & & & Glyma03g40680 & $\begin{array}{l}(\mathrm{M}=13) \\
\text { PTHR11732,,PTHR1 } \\
\text { 1732:SF253 - } \\
\text { ALDO,KETO } \\
\text { REDUCTASE }\end{array}$ \\
\hline decrease & gi|28974492 & $\begin{array}{l}\text { NAD-dependent } \\
\text { isocitrate dehydrogenase } \\
\text { alpha subunit [Brassica } \\
\text { napus }]\end{array}$ & & K00030 & $\begin{array}{l}\text { Microbial metabolism in diverse } \\
\text { environments, Metabolic pathways, } \\
\text { Carbon metabolism, Biosynthesis of } \\
\text { secondary metabolites, Biosynthesis of } \\
\text { antibiotics, Citrate cycle (TCA cycle), } \\
\text { Biosynthesis of amino acids, 2- } \\
\text { Oxocarboxylic acid metabolism }\end{array}$ & Glyma13g20790 & $\begin{array}{l}(\mathrm{M}=6) \text { 1.1.1.41 - } \\
\text { Isocitrate } \\
\text { dehydrogenase } \\
(\mathrm{NAD}(+)) \text {, } \\
\text { Nicotinamide adenine } \\
\text { dinucleotide isocitrate } \\
\text { dehydrogenase }\end{array}$ \\
\hline
\end{tabular}


Table 5: Continued

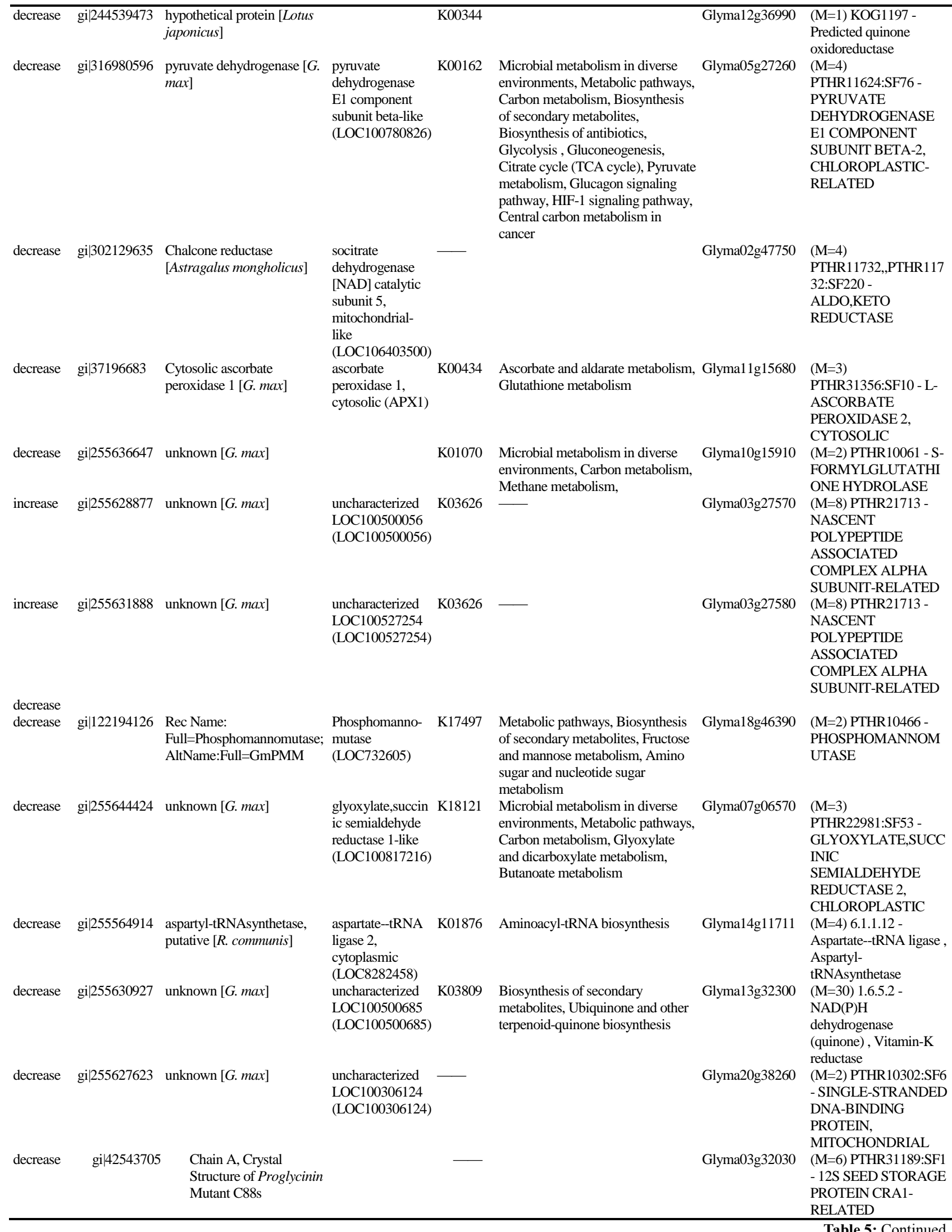


Yu et al. / Int. J. Agric. Biol., Vol. 19, No. 4, 2017

Table 5: Continued

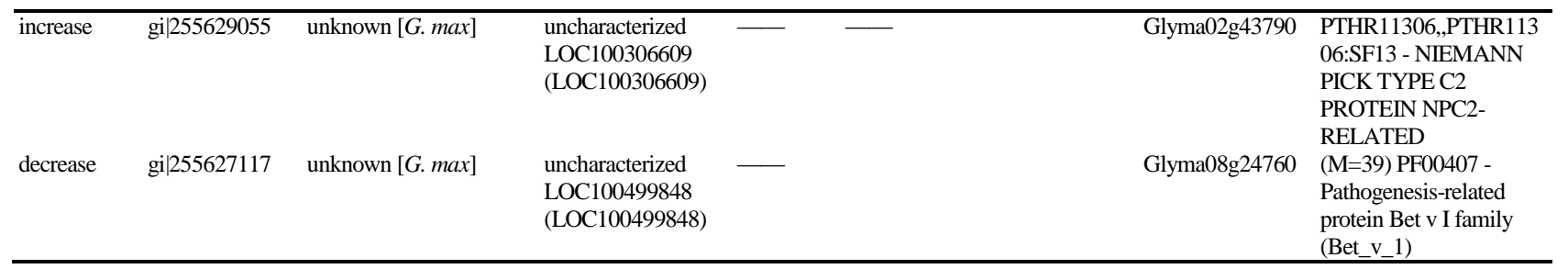

\section{Acknowledgements}

This work was supported by the National Natural Science Foundation of China (No. 31360338) and the Jiangxi Natural Science Foundation of China (20114BAB204014). We thank Dr. Lijuan Qiu and Dr. Kejing Wang from Chinese Academy of Agricultural Sciences, Dr. Tuanjie Zhao from Nanjing Agricultural University, and Ruizhen Wang from Jiangxi Academy of Agricultural Sciences for providing the soybean germplasm, and great support providing by the National Key Laboratory of Respiratory Disease of Guangzhou Medical University during the research of proteome.

\section{References}

Chen, Z., W. Yan, L. Sun, J. Tian and H. Liao, 2016. Proteomic analysis reveals growth inhibition of soybean roots by manganese toxicity is associated with alteration of cell wall structure and lignification. $J$. Proteomics, 143: 151-160

Deng, Y., K. Zhai, Z. Xie, D. Yang, X. Zhu, J. Liu, X. Wang, P. Qin, Y. Yang, G. Zhang, Q. Li, J. Zhang, S. Wu, J. Milazzo, B. Mao, E. Wang. H. Xie, D. Tharreau and Z. He, 2017. Epigenetic regulation of antagonistic receptors confers rice blast resistance with yield balance. Science, 355: 962-965

D'Ambrosio, C., S. Arena, M. Rocco, F. Verrillo, G. Novi, V. Viscosi, M. Marra and A. Scaloni, 2012. Proteomic analysis of apricot fruit during ripening. J. Proteomics, 78: 39-57

Kim, M.Y., S. Lee, K. Van, T.H. Kim, S.C. Jeong, I.Y. Choi, D.S. Kim, Y.S. Lee, D. Park, J. Ma, W.Y. Kim, B.C. Kim, S. Park, K.A. Lee, D.H Kim, K.H. Kim, J.H. Shin, Y.E. Jang, K.D. Kim, W.X. Liu, T. Chaisan, Y.J. Kang, Y.H. Lee, K.H. Kim, J.K. Moon, J. Schmutz, S.A. Jackson, J. Bhak and S.H. Lee, 2010. Whole-genome sequencing and intensive analysis of the undomesticated soybean (Glycine soja Sieb.and Zucc.) genome. PNAS, 107: 22032-22037

Li, C.M., S.P. Yang and J.Y. Gai and D.Y. Yu, 2007. Comparative proteomic analysis of wild (Glycine soja) and cultivated (Glycine max) soybean seeds. Prog. Biochem. Biophys., 34: 1296-1302

Liang, H.Z., Y,L. Yu, H.Q. Yang, L.J. Xu, W. Dong, H. Du, W.W. Cui and H.Y. Zhang, 2014. Inheritance and QTL mapping of related root traits in soybean at the seedling stage. Theor. Appl. Genet., 127: 2127-2137

Manavalan, L.P., S.J. Princ, T.A. Musket, J. Chaky, R. Deshmukh, T.D. Vuong, L. Song, P.B. Cregan, J.C. Nelson, J.G. Shannon, J.E. Specht and H.T. Nguyen, 2015. Identification of novel QTL governing root architectural traits in an interspecific soybean population. Plos One, 10: $\mathrm{e} 0120490$

Mathesius, U., M.A. Djordjevic, M. Oakes, N. Goffard, F. Haerizadeh, G.F. Weiller, M.B. Singh and P.L. Bhalla, 2011. Comparative proteomic profiles of the soybean (Glycine max ) root apex and differentiated root zone. Proteomics, 11: 1707-1719
Munoz, N., X. Qi, M.W. Li, M. Xie, Y. Gao, M.Y. Cheung, F.L. Wong and H.M. Lam, 2016. Improvement in nitrogen fixation capacity could be part of the domestication process in soybean. Heredity, 117: 84-93

Natarajan, S.S., C.P. Xu, W.M. Garrett, D. Lakshman and H. Bae, 2012 Assessment of the natural variation of low abundant metabolic proteins in soybean seeds using proteomics. J. Plant Biochem. Biotechnol., 21: 30-37

Prince, S.J., L. Song, D. Qiu, J.V.M.D. Santos, C. Chai, T. Joshi, G. Patil, B. Valliyodan, T.D. Vuong, M. Murphy, K. Krampis, D.N. Tucker, R. Biyashev, A.E. Dorrance, M.S. Maroof, D. Xu, J.G. Shannon and H.T. Nguyen, 2015. Genetic variants in root architecture-related genes in a Glycine soja accession, a potential resource to improve cultivated soybean. BMC Genom., 16: 132

Schmutz, J., S.B. Cannon, J. Schlueter, J. Ma, T. Mitros, W. Nelson, D.L. Hyten, Q. Song, J.J. Thelen, J. Cheng, D. Xu, U. Hellsten, G.D. May, Y. Yu, T. Sakurai, T. Umezawa, M.K. Bhattacharyya, D. Sandhu, B. Valliyodan, E. Lindquist, M. Peto, D. Grant, S. Shu, D. Goodstein, K. Barry, M. Futrell-Griggs, B. Abernathy, J. Du, Z. Tian, L. Zhu, N. Gill, T. Joshi, M. Libault, A. Sethuraman, X.C. Zhang, K. Shinozaki, H.T. Nguyen, R.A. Wing, P. Cregan, J. Specht, J. Grimwood, D. Rokhsar, G. Stacey, R.C. Shoemaker and S.A. Jackson, 2010. Genome sequence of the palaeopolyploid soybean. Nature, 463: 178-183

Wang, D., Z. Qu, D.L. Adelson, J.K. Zhu and J.N. Timmis, 2014. Transcription of nuclear organellar DNA in a model plant system. Genom. Biol. Evol., 6:1327-1334

Wang, G.Q., J.M. Lu and B. Hu, 2000. Evolutional structure study of vessel element on different evolvement type of Glycine L. J. Wuhan Bot. Res., 18: 271-274

Wang, J., L. Xu, X. Yun, K. Yang, D.J. Liao, L. Tian, H.J. Jiang and W.J. Lui, 2013. Proteomic Analysis Reveals that Proteasome Subunit Beta 6 Is Involved in Hypoxia-Induced Pulmonary Vascular Remodeling in Rats. PLoS One, 8: e67942

Wang, X. and S. Komatsu, 2016. Plant subcellular proteomics: Application for exploring optimal cell function in soybean. J. Proteomics, 143: $45-56$

Xu, C., T.J. Caperna, W.M. Garrett, P. Cregan, H. Bae, D.L. Luthria and S. Natarajan, 2007. Proteomic analysis of the distribution of the major seed allergens in wild, landrace, ancestral, and modern soybean genotypes. J. Sci. Food Agric., 87: 2511-2518

Yamasaki, M., S. Wright and M. Mcmullen, 2007. Genomic Screening for Artificial Selection during Domestication and Improvement in Maize. Ann. Bot., 100: 967-973

Zhu, Y.L., J. Wang and C. Yu, 1999. Two-Dimensional electrophoresis of plant proteins and a compound staining of coomassie brilliant blue and silver. J. Nanchang Univ. (Nat. Sci.), 23: 101-104

Zhu, J.Y., Z.S. Yang, Z.B. Liang, X.L. Li, X.D. Lian and J.M. Lu, 2003. Evolutional study on the root primary structure of Glycine L. $J$. Northeast Normal Univ., 35: 112-116

(Received 10 April 2017; Accepted 27 April 2017) 